\title{
IN VITRO ASSESSMENT OF ANTHELMINTIC AND ALPHA-AMYLASE INHIBITION OF SCHLEICHERA OLEOSA (LOUR.) OKEN LEAF EXTRACTS
}

\author{
SHAMBADITYA GOSWAMI ${ }^{1 *}$, RAVINDRA PAL SINGH ${ }^{2}$ \\ ${ }^{1}$ Department of Pharmacy, Research Scholar, Suresh Gyan Vihar University, Jaipur, Rajasthan, India. ${ }^{2}$ Department of Pharmacy, Faculty of \\ Pharmacy, Suresh Gyan Vihar University, Jaipur, Rajasthan, India. Email: shambampharma@gmail.com
}

Received: 07 July 2108, Revised and Accepted: 30 July 2018

\section{ABSTRACT}

Objective: The present study deals with the effects of Schleichera oleosa (Lour.) Oken leaf extracts on helminths and alpha-amylase inhibition. Identification of phytochemicals and physicochemical analysis were also performed.

Methods: Different concentrations $(25,50$, and $100 \mathrm{mg} / \mathrm{ml})$ of petroleum ether, acetone, chloroform, ethanol, and aqueous extracts of the leaf were used to examine the effects. For the evaluation of in vitro anthelmintic activity, several earthworms (Eisenia fetida, Perionyx excavates, and Pheretima posthuma) and nematode (Ascaridia galli) were taken, while albendazole was used as a standard drug and Tween $80(3 \%)$ in normal saline $(0.9 \%$ $\mathrm{NaCl})$ was considered as a control treatment. In vitro alpha-amylase inhibition of different extracts $(10-100 \mathrm{mg} / \mathrm{ml})$ was done spectrophotometrically by dinitrosalicylic acid - starch azure method.

Results: The ethanolic extract showed the maximum presence of phytochemicals among all the extracts, which included alkaloids, tannins, flavonoids, saponin glycosides, phenolic compounds, resins, and amino acids. The outcomes of the determination of physicochemical parameters and fluorescence characters provided the satisfactory results. Significant anthelmintic activity was established by the ethanolic and aqueous extracts of the leaf among all the extracts and the responses, so observed, were dose responsive. Inhibition of alpha-amylase by ethanolic and aqueous extracts was significant with the $\mathrm{IC}_{50}$ value of 36.63 and $73.94 \mu \mathrm{g} / \mathrm{ml}$, respectively, when compared to standard acarbose.

Conclusion: The ethanolic extract was the more potent candidate for both the effects, and the effect of extract was best against A. galli, P. posthuma, and E. fetida at higher concentration. Isolation and characterization of therapeutic constituents would be the future interest.

Keywords: Schleichera oleosa (Lour.) Oken, Earthworms, Nematodes, Anthelmintic activity, Alpha-amylase.

(C) 2018 The Authors. Published by Innovare Academic Sciences Pvt Ltd. This is an open access article under the CC BY license (http://creativecommons. org/licenses/by/4. 0/) DOI: http://dx.doi.org/10.22159/ajpcr.2018.v11i9.28338

\section{INTRODUCTION}

Schleichera oleosa (Lour.) Oken (family: Sapindaceae), is a deciduous tree available throughout Southeast Asia and India, is commonly known as "Kusum" and "Lac tree." The different parts of this plant have enormous traditional uses to treat different ailments. The leaves are used as fodder for domestic animals [1,2], whereas the bark paste is used for the treatment of malaria and dysentery. In the Himalayan area of Nepal, the fruits are used traditionally as anthelmintic [3], and the seed oil is used for acne, itching, hair growth, and burns; moreover, the whole plant is used as antidiabetic traditionally [4].

Helminthiasis is an extensive infection among the human beings distributed in the tropical region largely due to climate and unhygienic conditions $[5,6]$. Helminths include flatworms and roundworms or nematodes, which mainly affect the liver, skin, intestine, and liver [7]. To treat ailment like worm infection, usage of herbs is long practice [8-10]. Although the synthetic drugs of benzimidazole group such as albendazole and mebendazole are effective against tapeworms, hookworms, and roundworms [11], their long practice can cause severe side effects such as bone marrow depression and elevated liver enzymes [12].

Diabetes is an important and prior health problem which affected more than 400 million people globally in 2014 and caused 1.5 million deaths in 2012. There is the same alarming condition in Southeast Asia region along with India, and by 2035 , the condition will be the worst [13]. Several phytoconstituents of medicinal plants can decrease the postprandial glucose level by inhibiting alpha-amylase [14] as they facilitate the hydrolysis of the starch and its digestion $[15,16]$.
Nevertheless, the plant is used to treat helminthiasis and diabetes; traditionally, the scientific evaluations yet have not been done. Moreover, the phytochemical screening, physicochemical analysis, and fluorescence studies of the plant parts have been evaluated in the present research.

To evaluate the in vitro anthelmintic activity of different plant extracts, different earthworms such as Eisenia fetida (Family: Lumbricidae), Perionyx excavates (Family: Megascolecidae), and Pheretima posthuma (Family: Annelida) and nematodes (Ascaridia galli) have been selected in the present study for their anatomical and physiological uniformities with the intestinal worms.

\section{MATERIALS AND METHODS}

Plant material

The leaves of $S$. oleosa (Lour.) Oken were collected from the forest area of Nichlaul, Maharajganj district, Uttar Pradesh, in the flowering season of February and March 2017. The clean leaves were air dried for 3 months. Indian Council of Agricultural Research-Kamla Nehru Krishi Vigyan Kendra, Sultanpur, Uttar Pradesh, India (accession no. 02/2017), authenticated the plant parts.

\section{Preparation of crude extracts}

The shade dried coarsely powdered of leaves of the plant was subjected for successive solvent extraction according to the polarity. The different solvent extracts were petroleum ether (SEPE), chloroform (SECE), acetone (SEAcE), ethanol (SEEE), and water (SEAE). The cold maceration process was employed for the aqueous extract, and the continuous hot percolation process was employed for the others. After 
the extraction, the solvents were removed by distillation, and residues were preserved in the refrigerator at $2-8^{\circ} \mathrm{C}$ to use in the experiments.

\section{Preliminary phytochemical screening}

To confirm the presence or absence of different chemical constituents such as alkaloids, saponin glycosides, tannins, flavonoids, phenolic compounds, steroids, proteins, and amino acids, the preliminary phytochemical studies with different solvent extracts were performed according to the standard procedure [17].

\section{Physicochemical analysis}

The WHO recommended procedure was employed to evaluate different physicochemical parameters such as total ash, acid-insoluble ash and water-soluble ash values, extractive values with different solvents, loss on drying, and foreign matter [18]

\section{Fluorescence study}

The leaf powder and treated with different solvents were subjected for the fluorescence study. The observations were made under daylight, short UV light at $254 \mathrm{~nm}$, and long UV light at $365 \mathrm{~nm}$ [19].

\section{Collection and authentication of worms}

Different earthworms such as E. fetida, P. excavates, and P. posthuma were collected from moist soil and waterlogged areas. The domestic chicken (Gallus gallus) was freshly slaughtered to obtain the nematodes (A. galli). All the worms were washed with saline water to remove foreign and soil particles. Department of Zoology, HRPG College Khalilabad, Uttar Pradesh (Accession no: 09-Zoo-17), authenticated all the worms.

\section{In vitro anthelmintic activity}

In vitro anthelmintic activity was performed with all the extracts by taking different earthworms and nematodes according to the previous studies with slight modifications [5,20,21]. Almost equal sizes of P. posthuma, E. fetida, P. excavates, and A. galli were chosen (each group, $\mathrm{n}=6)$ for the activity. Similar studies using these models have been reported earlier [22-24].

The standard drug, albendazole, and all the extracts (dissolved in 3\% Tween 80 in normal saline) were prepared in 25, 50, and $100 \mathrm{mg} / \mathrm{ml}$ concentrations, while Tween $80(3 \%)$ in normal saline $(0.9 \% \mathrm{NaCl})$ was considered as control treatment and kept in separate Petri dishes, containing the worms. Paralysis time (PT in min) was noted while there was no motility of the worms even after extensive shaking and death time (DT in min) was recorded when there was a loss of motility even after dipping the worms in the warm water of $50^{\circ} \mathrm{C}$.

The statistical evaluation was performed by one-way ANOVA; the results were expressed as \pm standard deviation (SD) using Graph Pad Prism $7.4(n=6)$ and $p<0.05$ was considered statistically significant.

\section{In vitro alpha-amylase inhibition activity}

The assay was performed following the standard methods with minor modifications $[25,26] .0 .5 \% \mathrm{w} / \mathrm{v}$ starch solution was prepared by mixing $250 \mathrm{mg}$ starch azure in $50 \mathrm{ml}$ of $20 \mathrm{mM}$ sodium phosphate buffer (pH 6.9) with $6.7 \mathrm{mM} \mathrm{NaCl}$ at $\mathrm{pH} 65^{\circ} \mathrm{C}$ for $15 \mathrm{~min}$. Plant extracts were prepared in different concentrations from 10 to $100 \mathrm{mg} / \mathrm{ml}$ by dissolving in dimethyl sulfoxide (DMSO). $1 \mathrm{ml}$ of each plant extract was mixed with $1 \mathrm{ml}$ of enzyme solution, which was prepared by mixing $0.0253 \mathrm{~g}$ of alpha-amylase in $100 \mathrm{ml}$ cold distilled water. To the $1 \mathrm{ml}$ of this above solution, $1 \mathrm{ml}$ of starch solution was added, and the tube was incubated for $5 \mathrm{~min}$ at $25^{\circ} \mathrm{C}$. The colorimetric reagent was prepared by mixing 12 g sodium potassium tartrate tetrahydrate in $2 \mathrm{M} \mathrm{NaOH}(8 \mathrm{ml})$ and $96 \mathrm{mM}$ 3,5-dinitrosalicylic acid $(20 \mathrm{ml})$, which was added to the above solution and placed on a water bath at $80^{\circ} \mathrm{C}$ for 15 min followed by cooling and adding of $9 \mathrm{ml}$ distilled water.

Acarbose of different concentrations (10-100 mg/ml) was referred to standard drug. Blanks for each extract were prepared by omitting enzyme solution by phosphate buffer ( $\mathrm{pH}$ 6.9) and color reagent was added before the starch solution. Controls were prepared by taking $1 \mathrm{ml}$ DMSO instead of plant extract, the rest of the procedure was performed same as with plant extracts. The absorbance of standard, samples, and blanks was measured at $540 \mathrm{~nm}$ in UV spectrophotometer. The enzyme inhibitory activity was calculated by following formula:

Alpha - amylase inhibitory activity $(\%)=\frac{\Delta \text { AControl }-\Delta \text { ASample }}{\Delta \text { AControl }} \times 100$

Where, $\mathrm{A}=$ Absorbance

$\triangle \mathrm{A}$ Control=A of Test $-\mathrm{A}$ of Blank

$\Delta \mathrm{A}$ Sample $=\mathrm{A}$ of Test $-\mathrm{A}$ of Blank

The statistical evaluation was performed by linear regression analysis; the results were expressed as \pm SD using Graph Pad Prism $7.4(n=3)$. The results were analyzed by one-way ANOVA followed by Tukey's multiple comparison tests and $\mathrm{p}<0.0001$ was considered statistically significant.

\section{RESULTS AND DISCUSSION}

\section{Preliminary phytochemical screening}

The preliminary phytochemical screening of the plant leaf extracts affirmed the maximum presence of chemical constituents in SEEE and SEAE while comparing to others and the data have been tabulated in Table 1, which showed the presence of alkaloids, tannins, flavonoids, saponin glycosides, phenolic compounds, resins, and amino acids in SEEE.

The presence of these phytochemicals has a direct effect on helminthiasis. Alkaloid causes paralysis of helminths by interfering with local homeostasis which has the vital role in the development of worms [27]. Saponin glycosides, found in the wide variety of higher plants, can cause the damage integument and subsequent paralysis of the worms [6]. The previous literature described the presence of tannins in plant extracts can cause damage of cuticles of helminths by binding with the glycoproteins present on it $[28,29]$. Phenolic compounds and flavonoids are involved in energy generation process, damage in cuticle, and ultimately cause the paralysis and death of the worms [30].

Moreover, alkaloids, tannins, phenolic compounds, and flavonoids accelerate insulin secretion and reduce the absorption of glucose in intestine [31]. All these phytochemicals, as reported in literature, possess alpha-amylase inhibition activity [32]

\section{Physicochemical analysis and fluorescence study}

Plant leaf powder was subjected for the evaluation of different physicochemical parameters and fluorescence study, which represented the characteristic properties of the leaf of S. oleosa (Lour.) Oken. The results of the above studies were given in Tables 2 and 3, respectively.

Ash values were found to be the highest (6.21\%) while water-insoluble ash was the lowest (3.22\%). Extractive values were found mostly in the aqueous extract $(27.3 \%)$, followed by ethanolic extract $(26.1 \%)$, ethyl acetate, chloroform, acetone, and hexane extract.

Table 1: Preliminary phytochemical screening of Schleichera oleosa (Lour.) Oken leaf

\begin{tabular}{llllll}
\hline Phytochemicals & SEPE & SECE & SEAcE & SEEE & SEAE \\
\hline Alkaloids & - & - & - & + & - \\
Saponin glycosides & - & - & - & + & - \\
Tannins & - & + & + & + & + \\
Phenolic compounds & + & + & + & + & + \\
Flavonoids & - & - & - & + & + \\
Resins & - & - & - & + & - \\
Protein and amino acids & - & - & + & + & - \\
\hline
\end{tabular}

+ indicates "presence" and - indicates "absence" of phytochemicals in the test. SEPE: Solvent extracts of petroleum ether, SECE: Solvent extracts of chloroform, SEAcE: Solvent extracts of acetone, SEEE: Solvent extracts of ethanol,

SEAE: Solvent extracts of water 
In vitro anthelmintic activity

For the support of the folkloric use of $S$. oleosa (Lour.) Oken as anthelmintic [3], an in vitro assay was performed by noting down the PT and lethal time in minutes of all extracts. Due to the anatomical and physiological resemblance with the human intestinal worms and parasites, different earthworms and nematodes were selected for the activity. In the observed results, the earthworms and nematodes likely E. fetida, $P$. excavates, $P$. posthuma, and A. galli were denoted as EP, PE, $\mathrm{PP}$, and AG, respectively. The effect on all the worms of standard drug albendazole was significant and dose dependent which supports the reported related literature $[33,34]$

At the concentration of $100 \mathrm{mg} / \mathrm{ml}$, the standard drug was more effective against all worms. The results were presented in graphical form; Figs. 1-3 described the effect of plant extract on EP, PE, PP, and AG at different concentrations. There was no effect on the worms in control treatment as the worms were healthy throughout the experiment.

Among all the extracts, SEEE is considered more effective against all the earthworms and nematodes while comparing with others. Moreover, SEEE showed greater effect on $A$. galli (DT: $41.03 \pm 4.21$ minutes at $100 \mathrm{mg} / \mathrm{ml}$ ) with the increasing dose than the other earthworms, and among the earthworms, the extract has greater significant effect on E. fetida (DT: $56.1 \pm 2.41 \mathrm{~min}$ at $100 \mathrm{mg} / \mathrm{ml}$ ) and P. posthuma (DT: $57.1 \pm 5.48 \mathrm{~min}$ at $100 \mathrm{mg} / \mathrm{ml}$ ) while comparing to P. excavates (DT: $62.31 \pm 3.44 \mathrm{~min}$ at $100 \mathrm{mg} / \mathrm{ml}$ ). It has been reported in earlier studies that the ethanolic extract of Clerodendrum viscosum was more effective against $A$. galli than P. posthuma in 50, 100, and $200 \mathrm{mg} / \mathrm{ml}$ dose [35]. Likewise, at lower concentration (10 and $50 \mathrm{mg} / \mathrm{ml}$ ), Baliospermum montanum Muell. Arg. was proved as potent anthelmintics against A. galli than P. posthuma. At the higher concentration, the plant was equally potent against them. In addition, this study has reported that the ethanolic extract was more potent than aqueous extract [36].

Table 2: Physicochemical analysis of Schleichera oleosa (Lour.) oken leaf

\begin{tabular}{lll}
\hline Sr. No & Parameters & Value \\
\hline 1. & Ash values & \\
& Total ash & $6.21 \% \mathrm{w} / \mathrm{w}$ \\
& Acid-insoluble ash & $4.72 \% \mathrm{w} / \mathrm{w}$ \\
& Water-soluble ash & $3.22 \% \mathrm{w} / \mathrm{w}$ \\
2. & Extractive values with organic solvent & \\
& Hexane & $8.2 \% \mathrm{w} / \mathrm{w}$ \\
& Chloroform & $12.3 \% \mathrm{w} / \mathrm{w}$ \\
& Acetone & $9.7 \% \mathrm{w} / \mathrm{w}$ \\
& Ethyl acetate & $17.2 \% \mathrm{w} / \mathrm{w}$ \\
& Ethanol & $26.1 \% \mathrm{w} / \mathrm{w}$ \\
3. & Water & $27.3 \% \mathrm{w} / \mathrm{w}$ \\
4. & Loss on drying & $5.7 \pm 0.3 \mathrm{mg} / \mathrm{g}$ \\
\hline
\end{tabular}

Table 3: Fluorescence analysis of Schleichera oleosa (Lour.) Oken leaf

\begin{tabular}{lllll}
\hline Sr. No & Reagents & Daylight & Short UV & Lower UV \\
\hline 1. & Leaf Powder (LP) & $\mathrm{DG}$ & $\mathrm{Bl}$ & $\mathrm{YG}$ \\
2. & $\mathrm{LP}+1 \mathrm{~N} \mathrm{HCl}$ & $\mathrm{GBr}$ & $\mathrm{Br}$ & $\mathrm{DBr}$ \\
3. & $\mathrm{LP}+\mathrm{HCl}(50 \%)$ & $\mathrm{GBl}$ & $\mathrm{DBr}$ & $\mathrm{DG}$ \\
4. & $\mathrm{LP}+1 \mathrm{~N} \mathrm{NaOH}_{2}$ & $\mathrm{YG}$ & $\mathrm{DBr}$ & $\mathrm{GBl}$ \\
5. & $\mathrm{LP}_{2} \mathrm{SO}_{4}(50 \%)$ & $\mathrm{GBr}$ & $\mathrm{DBl}$ & $\mathrm{RBr}$ \\
6. & $\mathrm{LP}_{\mathrm{HNO}}(50 \%)$ & $\mathrm{YG}$ & $\mathrm{LBl}$ & $\mathrm{GBl}$ \\
7. & $\mathrm{LP}+\mathrm{NH}_{3}$ & $\mathrm{LG}$ & $\mathrm{RG}$ & $\mathrm{DG}$ \\
8. & $\mathrm{LP}+\mathrm{GAA}$ & $\mathrm{GBl}$ & $\mathrm{LBr}$ & $\mathrm{RBr}$ \\
9. & $\mathrm{LP}+\mathrm{Ethanol}$ & $\mathrm{GBr}$ & $\mathrm{GBr}$ & $\mathrm{DG}$ \\
10. & LP+KOH $(50 \%)$ & $\mathrm{YG}$ & $\mathrm{LG}$ & $\mathrm{DG}$ \\
\hline
\end{tabular}

LP: Leaf powder, GAA: Glacial acetic acid, L: Light, D: Dark, G: Green, Br: Brown, Bl: Black, BrR: Brownish-red, GBr: Greenish-brown, GBl: Greenish-black, RBr: Reddish-brown, YG: Yellowish-green, YBr: Yellowish-brown
The present study also confirmed that SEEE was more effective than SEAE. In the case of SEAE, the effectiveness was more against the nematode (DT: $59.21 \pm 3.56 \mathrm{~min}$ at $100 \mathrm{mg} / \mathrm{ml}$ ), and almost equal against the earthworms. In the earlier literature, the significant anthelmintic activity of chloroform extract of other plants against earthworms has been reported $[37,38]$. Tannins containing acetone extract were evaluated for the anthelmintic activity against Haemonchus contortus egg hatching in the previous literature which was considered as potent anthelmintics [39]. Similarly, this present paper also described the

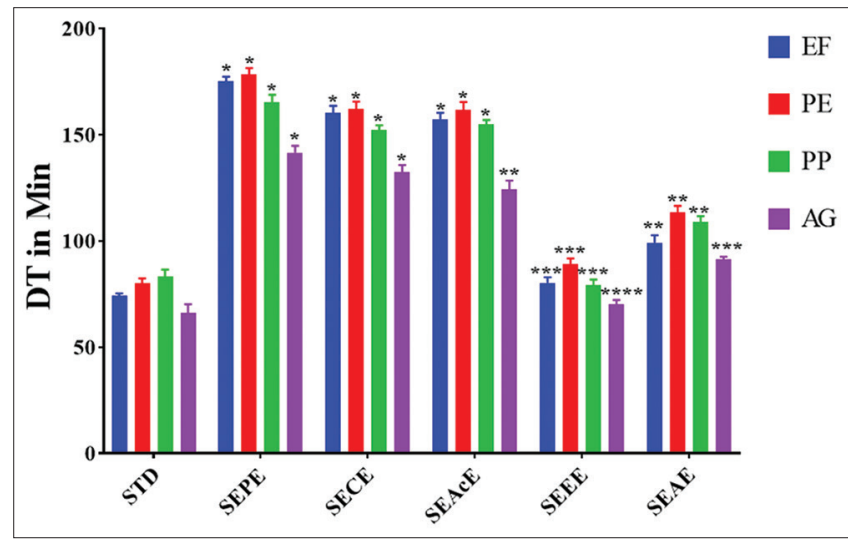

Fig. 1: The anthelmintic activity of Schleichera oleosa (Lour.) Oken leaf extracts at $25 \mathrm{mg} / \mathrm{ml}$. All values represent mean \pm standard deviation; $n=6$ in each group; $p<0.05$ was considered statistically significant

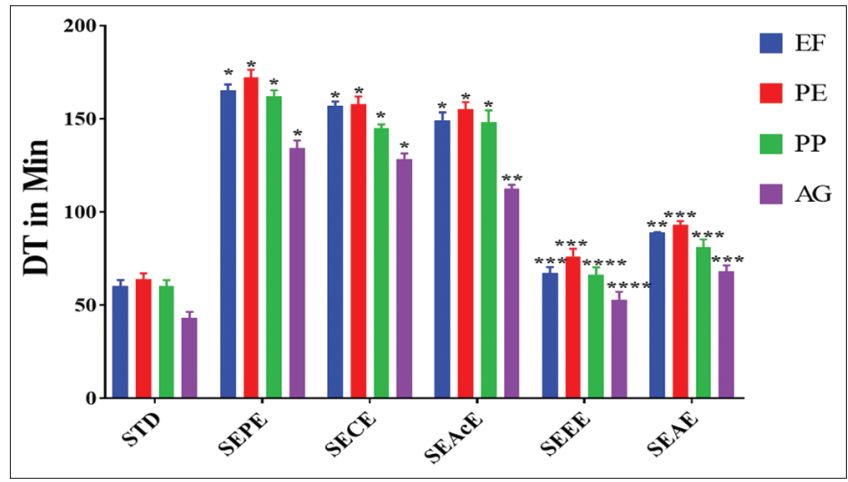

Fig. 2: The anthelmintic activity of Schleichera oleosa (Lour.) Oken leaf extracts at $50 \mathrm{mg} / \mathrm{ml}$. All values represent mean \pm standard deviation; $n=6$ in each group; $p<0.05$ was considered statistically significant

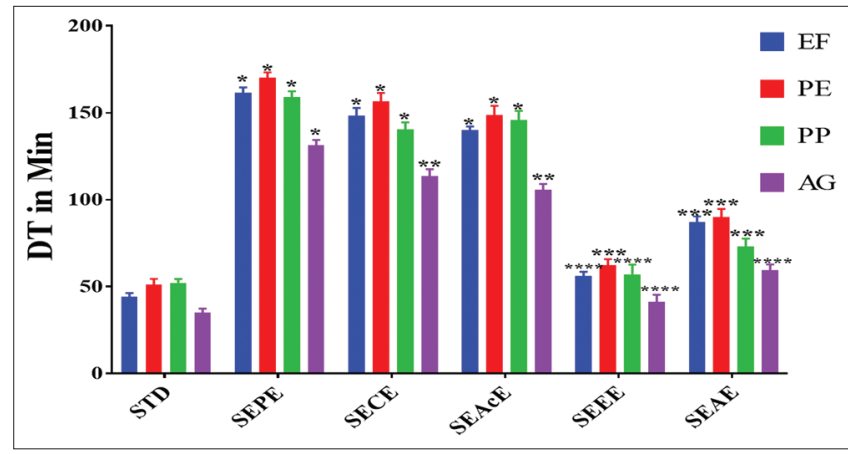

Fig. 3: The anthelmintic activity of Schleichera oleosa (Lour.) Oken leaf extracts at $100 \mathrm{mg} / \mathrm{ml}$. All values represent mean \pm standard deviation; $n=6$ in each group; $p<0.05$ was considered statistically significant 


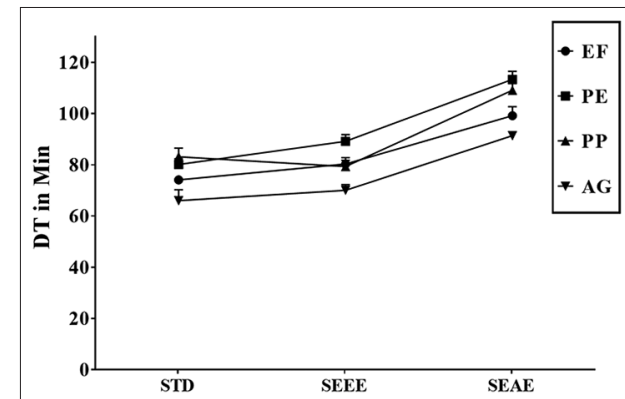

a
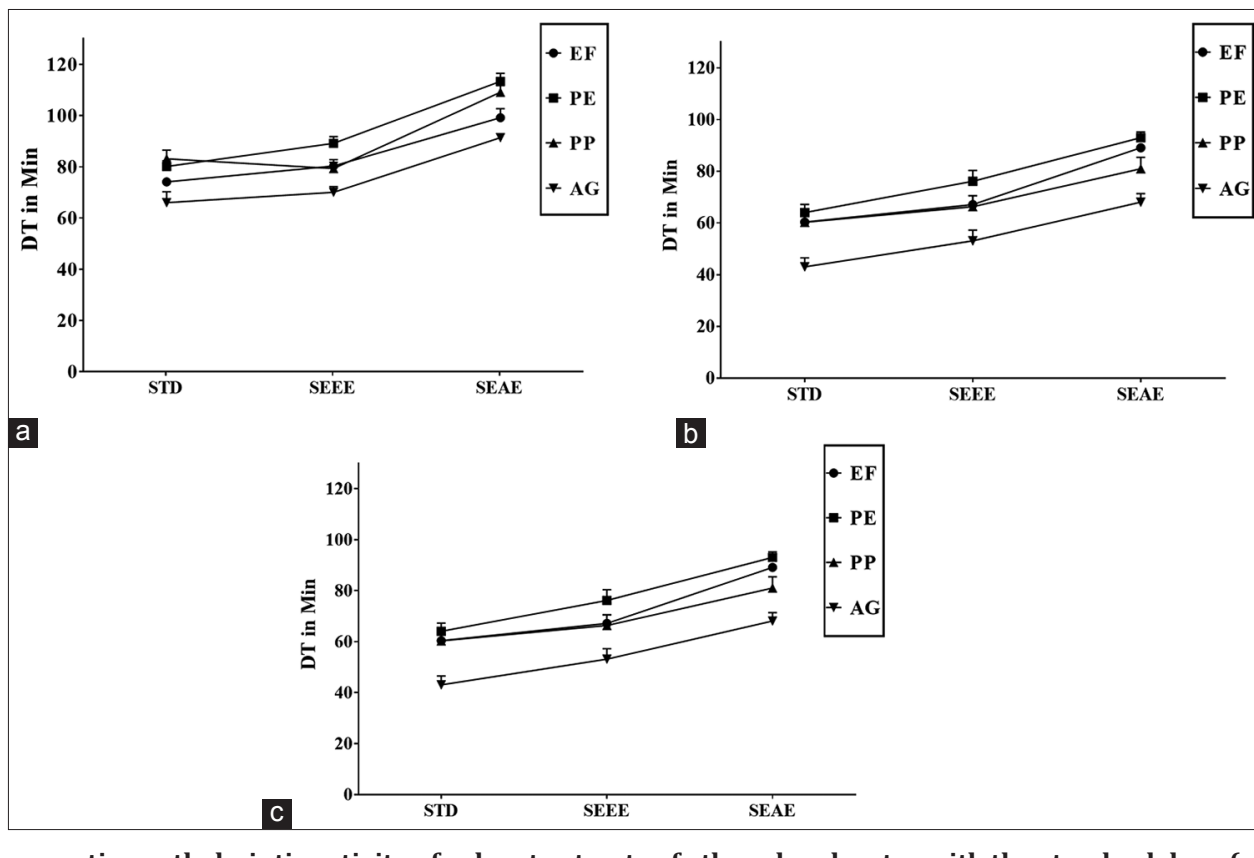

Fig. 4: The comparative anthelmintic activity of solvent extracts of ethanol and water with the standard drug (albendazole) at

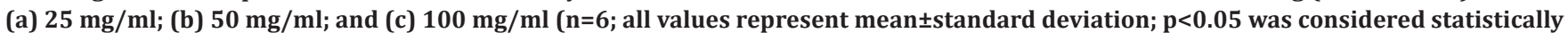
significant)

significant effect of the SECE and SEAcE on A. galli (DT: $113.45 \pm 4.11 \mathrm{~min}$ and $105.78 \pm 3.25 \mathrm{~min}$ at $100 \mathrm{mg} / \mathrm{ml}$, respectively) but not as significant as the ethanolic one. The results also exhibited the poor effect of SEPE extract had a very little effect on the worms.

The results exhibited clearly the effects of all the extracts were dose dependent; at $25 \mathrm{mg} / \mathrm{ml}$, SEEE was more effective against all the worms and SEAE was found effective against A. galli (Fig. 4a). In Fig. 4b, it has been found that at $50 \mathrm{mg} / \mathrm{ml}$ dose SEEE showed best result against A. galli than P. posthuma. At the higher concentration, $100 \mathrm{mg} / \mathrm{ml}$, the response of SEEE and SEAE was most potent against the nematodes (Fig. 4c).

\section{In vitro alpha-amylase inhibition activity}

Inhibitor of alpha-amylase enzyme is a better oral hypoglycemic agent as they control diabetes by interfering with the absorption of glucose [40]. The present evaluation of in vitro alpha-amylase inhibition was done by dinitrosalicylic acid - starch azure method, for the support of its traditional use as an antidiabetic plant. At the range of $10-100 \mathrm{mg} / \mathrm{ml}$, standard drug (acarbose) exhibited alpha-amylase inhibition $19.25 \pm 0.06-62.38 \pm 0.05\left(\mathrm{IC}_{50}\right.$ value 78.56 ), whereas SEEE and SEAE showed the inhibition in the same concentration range from $32.40 \pm 0.95$ to $83.51 \pm 1.0\left(\mathrm{IC}_{50}\right.$ value 36.63 ) and $19.62 \pm 0.90$ to $62.30 \pm 2.03$ (IC ${ }_{50}$ value 73.94), respectively. Similar studies of the plant S. oleosa (Lour.) Oken showed similar effect; at the lower concentration $(1-50 \mathrm{mg} / \mathrm{ml})$, ethanolic and aqueous extract showed better inhibition activity while comparing to other extracts of ethyl acetate, pet ether, and chloroform [41]. The present study revealed that at higher concentration $(60-100 \mathrm{mg} / \mathrm{ml})$ also ethanolic and aqueous extracts were more significant than others. Figs. 5 and 6 represented the comparison of alpha-amylase inhibition activity and the $\mathrm{IC}_{50}$ values of different extracts while compared to acarbose, respectively. At $100 \mu \mathrm{g} / \mathrm{ml}$, the enzyme inhibition of the other extracts: SEPE (19.53 \pm 0.16$)$, SECE $(33.39 \pm 1.31)$, and SEAcE $(45.61 \pm 2.08)$ proved SEEE and SEAE more potent.

\section{CONCLUSION}

The present study unrevealed the plant S. oleosa (Lour.) Oken as a potent anthelmintics and antidiabetics supporting the traditional beliefs. The

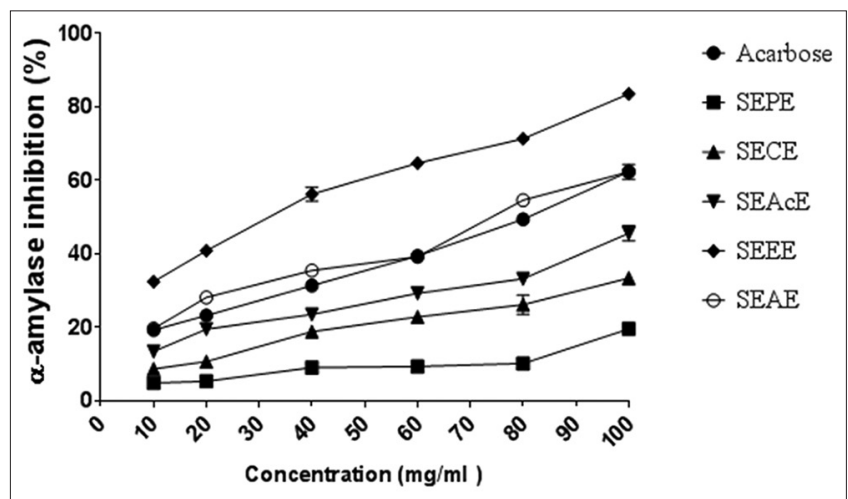

Fig. 5: Alpha-amylase inhibition of Schleichera oleosa (Lour.) Oken leaf extracts compared to standard (acarbose) (n=triplicate; all values express mean \pm standard deviation)

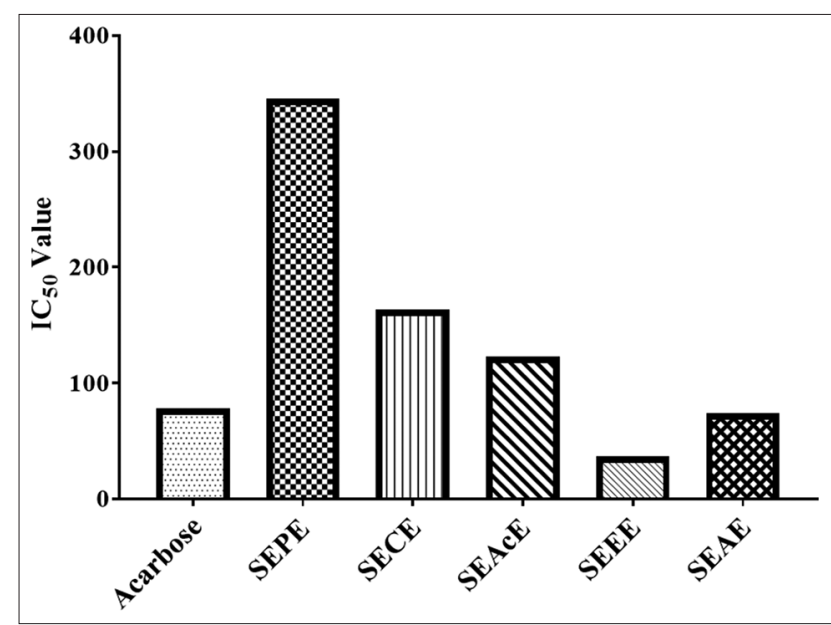

Fig. 6: IC I0 $_{5}$ values of Schleichera oleosa (Lour.) Oken leaf extracts compared to standard (acarbose) 
ethanolic and aqueous extract of the plant was manifested as more effective against helminthiasis, especially against the nematodes, as well as showed better alpha-amylase inhibition activity. The identification of the secondary metabolites of the plant parts to explore the constituents responsible for the activity and molecular level mechanism will be the future interest.

\section{AUTHORS' CONTRIBUTION}

Goswami Shambaditya: Performs all experimental works, designing of results, and manuscript preparations. Singh Ravindra Pal is a research advisor and performs statistical analysis and manuscript editing. Both the authors read and approved the final manuscript.

\section{CONFLICTS OF INTEREST}

The authors declare that there are no conflicts of interest.

\section{REFERENCES}

1. Devendra C, Thomas D, Jabbar MA, Zerbini E. Improvement of Livestock Production in Crop-Animal Systems in Agro-ecological Zones of South Asia. Nairobi, Kenya: International Livestock Research Institute (ILRI); 2000

2. Meshram N, Ojha M, Singh A, Alexander A, Sharma M. Significance and traditional medicinal properties of Schleichera oleosa. Asian J Pharm Res 2015;5:61-4

3. Prasad B, Subedi L. Medicinal Plant Diversity and their Pharmacological aspects of Nepal Himalayas. Pharmacognnosy J 2011;3:6-17.

4. Goswami S, Singh RP. Aurvedic,phytochemical and pharmacological review of Schleichera oleosa (Lour.) Oken: A traditional plant with enormous biological activity. World J Pharm Res.2017;6:295-309.

5. Goswami S, Mishra KN, Mishra A, Singh AP, Singh P, Singh P. Comparative assessment of in-vitro anthelminthic studies of some plants from Indian origin. J Pharm Res 2016;1010:514-8

6. Hrckova G, Velebny S. Parasitic helminths of humans and animals: Health impact and control. In: Pharmacological Potential of Selected Natural Compounds in the Control of Parasitic Diseases. $1^{\text {st }}$ ed. Vienna: Springer-Verlag Wien; 2013. p. 29-99.

7. Wakelin D. Helminths: Pathogenesis and defenses. In: Baron S, editor. Medical Microbiology. $4^{\text {th }}$ ed. Galveston (TX): University of Texas Medical Branch at Galveston; 1996.

8. Goswami S, Nishad S, Rai M, Madhesiya S, Malviya A, Pandey P. Plant seeds used for anthelmintic activity: A review. Indian J Res Pharm Biotechnol 2013;1:533-6.

9. Ukwubile CA. Anti-helminthic properties of some Nigerian medicinal plants on selected intestinal worms in children (Age 5-13) in Ogurugu, South East Nigeria. J Bacteriol Parasitol 2012;3:159.

10. Singh R, Mehta A, Mehta P, Shukla K. Anthelmintic activity of rhizome extracts of Curcuma longa and Zingiber officinale (Zingiberaceae). Int J Pharm Pharm Sci 2011;3 Suppl 2:236-7.

11. Vardanyan RS, Hruby VJ. Synthesis of Essential Drugs. $1^{\text {st }}$ ed. Amsterdam: Elsevier Science; 2006.

12. Block JH, Beale JM, editors. Wilson and Gisvold's Textbook of Organic Medicinal and Pharmaceutical Chemistry. Philadelphia, PA: Lippincott Williams and Wilkins; 1998.

13. WHO. Global Reports on Diabetes. Geneva: WHO; 2016.

14. Funke I, Melzig MF. Traditionally used plants in diabetes therapy: Phytotherapeutics as inhibitors of alpha-amylase activity. Rev Bras Farmacogn 2006;16:1-5.

15. Agarwal P, Gupta R. Alpha-amylase inhibition can treat diabetes mellitus. J Med Heal Sci 2016;5:1-8

16. Gawade B, Farooqui M. Screening of phytochemicals and in vitro antidiabetic activity of Bauhinia racemosa Lam. leaves. Asian J Pharm Clin Res 2018;11:190-3.

17. Khandelwal KR. Practical Pharmacognosy: Techniques and Experiments. $16^{\text {th }}$ ed. New Delhi: Nirali Prakashan; 2008.

18. WHO. Quality Control Methods for Medicinal Plant Materials. Geneva: WHO; 1998.
19. Goswami S. Preliminary phytochemical screening and standardisation of leaves of Catharanthus roseus (L.) G. Don. Indian J Res Pharm Biotechnol 2009;1:24-7.

20. Pandey A, Goswami S, Tripathi P, Singh AP. An in vitro evaluation of anthelmintic activity of Zingiber zerumbet rhizomes and Cucurbita maxima seeds on Pheretima posthuma model: A comparative study. J Pharm Bioallied Sci 2011;3:317.

21. Manke MB, Dhawale SC, Jamkhande PG. Anthelmintic potential of Helicteres isora bark extract against Pheretima posthuma. Asian Pac J Trop Dis 2015;5:313-5

22. Cáceres AL, Flores-Giubi ME, Romero-Rodríguez MC, Alvarenga NL, In vitro anthelmintic activity and chemical composition of methanol extracts and fractions of Croton paraguayensis and Vernonia brasiliana against Eisenia fetida. Asian Pac J Trop Dis 2015;7:71-4.

23. Karthi J, Thamizhmozhi M, Saravanan C, Ahamed KA, Niruban KC. In vitro anthelmintic activity of leaves extracts of Caesalpinia bonducella (L). Pharm Lett 2011;3:317-9.

24. Eman KA, El-Bahy NM. In vitro and in vivo screening of anthelmintic activity of ginger and curcumin on Ascaridia galli. Parasitol Res 2013;112:3679-86.

25. Nickavar B, Abolhasani L, Izadpanah H. $\alpha$-Amylase inhibitory activities of six Salvia species. Iran J Pharm Res 2008;7:297-303.

26. Giancarlo S, Rosa LM, Nadjafi F, Francesco M. Hypoglycaemic activity of two spices extracts: Rhus coriaria L. and Bunium persicum Boiss. Nat Prod Res 2006;20:882-6.

27. Lavanya B, Krishna PS, Nagarjuna S, Reddy YP. In-vitro comparative study of anthelmintic activity of Brassica juncea and Brassica oleracea. J Pharm Res 2011:4:2907-9.

28. Balqis U, Hambal M, Rinidar, Athaillah F, Ismail, Azhar, et al. Cuticular surface damage of Ascaridia galli adult worms treated with Veitchia merrillii betel nuts extract in vitro. Vet World 2017;10:732-7.

29. Williams AR, Ropiak HM, Fryganas C, Desrues O, Mueller-Harvey I, Thamsborg SM. Assessment of the anthelmintic activity of medicinal plant extracts and purified condensed tannins against free-living and parasitic stages of Oesophagostomum dentatum. Parasit Vectors 2014;7:518.

30. Agrawal S, Bhawsar A, Choudhary P, Singh S, Keskar N, Chaturvedi M. In-vitro anthelmintic activity of Kaempferia rotunda. Int J Pharm life Sci 2011;2:1062-4

31. Kooti W, Farokhipour M, Asadzadeh Z, Ashtary-Larky D, AsadiSamani M. The role of medicinal plants in the treatment of diabetes: A systematic review. Electron Physician 2016;8:1832-42.

32. Melappa G. A review on role of plant(s) extracts and its phytochemicals for the management of diabetes. J Diabetes Metab 2015;6:565.

33. Goswami S, Pandey A, Tripathi P, Singh A, Rai A. An in vitro evaluation of the anthelmintic activity of Hedychium spichatum rhizomes and Zingiber zerumbet rhizomes on the Pheritima posthuma model: A comparative study. Pharmacog Res 2011;3:140-2.

34. Lalchhandama K, Roy B, Dutta BK. Anthelmintic activity of Acacia oxyphylla stem bark against Ascaridia galli. Pharm Biol 2009; 47:578-83.

35. Das JK, Choudhury S, Adhikary S. Anthelmintic activity of Clerodendrum viscosum. Orient Pharm Exp Med 2011;11:119-22.

36. Mali RG, Wadekar RR. In vitro anthelmintic activity of Baliospermum montanum Muell. Arg roots. Indian J Pharm Sci 2008;70:131-3.

37. Raghavamma ST, Rao NR. In vitro evaluation of anthelmintic activity of Nauclea orientalis leaves. Indian J Pharm Sci 2010;72:520-1.

38. Kanthal LK, Bhar K, Ravali P, Sahoo S, Anusha N. GC-MS analysis and anthelmintic activity of chloroform extract of Lantana camara L. Int J Dev Res 2016;6:10367-70.

39. Fouche G, Sakong BM, Adenubi OT, Pauw E, Leboho T, Wellington KW, et al. Anthelmintic activity of acetone extracts from South African plants used on egg hatching of Haemonchus contortus. Onderstepoort J Vet Res 2016;83:7.

40. Khatri DK, Juvekar AR. $\alpha$-glucosidase and $\alpha$-amylase inhibitory activity of Indigofera cordifolia seeds and leaves extract. Int J Pharm Pharm Sci 2014;6:152-5.

41. Muthukrishnan S, Sivakkumar T. In vitro studies to assess the antidiabetic potential of Schleichera oleosa (lour) oken leaves. Asian J Pharm Clin Res 2017;10:280-3. 